\title{
Antidiabetic of Mango (Mangifera longipes Griff.) Leves: Methanol Extract, Water Fraction, and Ethyl Acetate
}

\author{
Nur Rahayuningsih*, Piranti, Diana S. Zustika \\ Department of Pharmacology and Pharmacy Clinic, STIKes Bakti Tunas Husada, Tasikmalaya, Indonesia
}

Submitted 30 November 2021; Revised 09 December 2021; Accepted 09 December 2021; Published 30 December 2021

*Corresponding author: nur.rahayuridwan@gmail.com

\begin{abstract}
Mango leaves (Mangifera longipes Griff.) are used for diabetic, malaria, gastrointestinal, kidney, as well as topical treatment of wounds. The aim of this study was to determine the antidiabetic activity of methanol extract, water fraction and ethyl acetate fraction from mango leaves (Mangifera longipes Griff.). Oral Glucose Tolerance Test (OGTT) on 24 rats divided into 6 groups, namely normal; negative; positive (given acarbose $1.8 \mathrm{mg} / 200 \mathrm{~g} \mathrm{BW}$ rats); methanol extract (EM), water fraction (FA), ethyl acetate fraction (FEA) with a dose of $58.8 \mathrm{mg} / 200 \mathrm{~g} \mathrm{BW}$ rats. Induction of $1.35 \mathrm{~g} / 200 \mathrm{~g}$ BW of rats glucose was carried out 30 minutes before the dosage administration. Data analysis with Paired T Test (95\% confidence level). Results: In crude extract standardization, the water content was $2 \%$, the ash content was $12.6 \%$ and the water soluble extract content was $19.5 \%$. In crude extract and EM, flavonoids, saponins, and phenols were identified; in FA identified saponins and phenols; FEA identified flavonoids and phenols. A significant decrease in blood glucose levels at T0 and T120 in all groups (significant 2-tailed $<0.05$ ). The percentage of decline in the positive and FEA groups compared to the negative was $85.5 \%$ and $16.9 \%$, respectively. Discussion:. Flavonoids are thought to increase antioxidant activity and inhibit $\alpha$-glucosidase enzymes. Conclusion: EM, FA and FEA have antidiabetic activity with the best percentage reduction in glucose levels was FEA (16.9\%).
\end{abstract}

Keywords: Antidiabetic, OGTT, Mangifera longipes Griff

\section{Antidiabetes Daun Mangga (Mangifera longipes Griff.) : Ekstrak Metanol, Fraksi Air, dan Etil Asetat}

\begin{abstract}
Abstrak
Daun mangga (Mangifera longipes Griff.) digunakan untuk pengobatan diabetes, malaria, gastrointestinal, ginjal, serta pengobatan topikal luka. Penelitian ini bertujuan untuk mengetahui aktivitas antidiabetes ekstrak metanol, fraksi air dan fraksi etil asetat dari daun mangga (Mangifera longipes Griff.). Uji Toleransi Glukosa Oral (TTGO) pada 24 ekor tikus yang dibagi menjadi 6 kelompok yaitu normal; negatif; positif (diberi acarbose $1,8 \mathrm{mg} / 200 \mathrm{~g}$ BB tikus); ekstrak metanol (EM), fraksi air (FA), fraksi etil asetat (FEA) dengan dosis $58,8 \mathrm{mg} / 200 \mathrm{~g}$ BB tikus. Induksi glukosa dosis $1,35 \mathrm{~g} / 200 \mathrm{~g} \mathrm{BB}$ tikus dilakukan 30 menit sebelum pemberian sediaan uji. Analisis data dengan Paired T Test (tingkat kepercayaan 95\%). Berdasarkan standarisasi ekstrak diperoleh kadar air 2\%, kadar abu 12,6\% dan kadar ekstrak larut air 19,5\%. Dalam simplisia dan EM, teridentifikasi flavonoid, saponin, dan fenol; dalam FA teridentifikasi saponin dan fenol; dalam FEA teridentifikasi flavonoid dan fenol. Terjadi penurunan kadar glukosa darah yang bermakna pada T0 dan T120 pada semua kelompok (signifikan 2-tailed < 0,05). Persentase penurunan pada kelompok positif dan FEA dibandingkan dengan kelompok negatif masing-masing $85,5 \%$ dan $16,9 \%$. Flavonoid diduga dapat meningkatkan aktivitas antioksidan dan menghambat enzim -glukosidase. EM, FA dan FEA memiliki aktivitas antidiabetes dengan persentase penurunan kadar glukosa yang paling baik adalah FEA (16,9\%).
\end{abstract}

Kata Kunci: Antidiabetes, OGTT, Mangifera longipes Griff 


\section{Introduction}

The group of metabolic diseases caused by abnormalities in insulin secretion or action or both, causing hyperglycemia characteristics is the definition of diabetes mellitus. ${ }^{1}$ Diabetes can also be defined as a group of metabolic disorders characterized and identified by the presence of hyperglycemia without treatment. ${ }^{2}$ According to $\mathrm{WHO}$, between 2000 and 2016 deaths from diabetes increased by $5 \% .^{3}$ Diabetes is categorized into 4 classification, namely type 1 diabetes mellitus, type 2 diabetes mellitus, gestational diabetes mellitus, and certain types of diabetes due to other causes. ${ }^{4}$

Mango leaves are a source of pharmacologically active mangiferin. ${ }^{5}$ Mangiferin has properties as antidiabetic, antidyslipidemic, antitussive, expectorant, antiasthmatic, central depression, antioxidant, anti-inflammatory, bacteriostatic, antiviral, anti-tumor, choleretic, and immunomodulatory. ${ }^{6,7}$ Mangiferin can be used as an antidiabetic by inhibiting $\alpha$-glucosidase. ${ }^{8}$ Mango leaves contain phenolic compounds (gallic acid and its derivatives, ellagic acid, strong protocatechin); Xanthones (Mangiferin and its derivatives); Flavonoids (Quercetin and its derivatives, Rhamnetin and its derivatives); Benzophenone (Maclurin and its derivatives, Iriflofenon Glycoside and its derivatives); Triterpenoids (Lupeol). ${ }^{9}$ Mangiferin has consistent antidiabetic activity, with a peak 7 hours after oral administration. Mangiferin exhibits its antidiabetic activity by increasing insulin sensitivity. ${ }^{10}$

Previous research has been carried out on the ethanol extract of mango leaves of the Arumanis variety, and it was found that at a dose of $8.4 \mathrm{mg} / 20$ grams of body weight, mice were effective in lowering blood glucose levels. ${ }^{11}$ The aim of this study was to determine the antidiabetic activity of methanol extract, water fraction and ethyl acetate fraction from mango leaves (Mangifera longipes G.). In this study, compounds were separated based on their polarity differences.

\section{Materials and Methods}

2.1. Alat dan Bahan
Macerator (RRC, PT.Andesya Abadi Labtek), oral sonde (RRC, PT.Dipa Prasa Husada), syringe (Terumo, CV.Ayubi Medika), dropper (Lokal, CV.Ayubi Medika), test tube (Iwaki Pyrex, CV.Ayubi Medika), beaker glass (Iwaki Pyrex, PT.Andesya Abadi Labtek), stirring rod (RRC, PT.Andesya Abadi Labtek), filter paper (Whatman 41, PT.Dipa Prasa Husada), separating funnel (Iwaki Pyrex, PT.Andesya Abadi Labtek), desiccator (RRC, PT.Andesya Abadi Labtek), rotary vacuum evaporator (IKA Jerman, PT.Andesya Abadi Labtek), measuring cup (Pyrex, Asia Plaza), glucometer (Easy Touch GCU), silicate crucible (RRC, PT.Andesya Abadi Labtek), cup, microscope (RRC, PT.Andesya Abadi Labtek), oven (Memert, PT.Andesya Abadi Labtek).

Mango leaves (Mangifera longipes G.) obtained from the Sukamanah Tasikmalaya were determined at the Jatinangor Herbarium, Plant Taxonomy Laboratory, Department of Biology, UNPAD on January 15, 2021 with No. 31/HB/01/2021. Acarbose (Acarbose, OGB Dexa), glucose (Merck, PT.Dipa Prasa Husada), toluene (Merck, PT.Dipa Prasa Husada), aqua dest (IKA Farmindo, PT.Dipa Prasa Husada), chloroform (Smartlab, PT.Dipa Prasa Husada), ethanol (Smartlab, PT.Dipa Prasa Husada), NH4OH (Teknis, PT.Dipa Prasa Husada), HCl (Merck, PT.Dipa Prasa Husada), Dragendrof's reagent, mayer's reagent, Mg powder (Teknis, PT.Dipa Prasa Husada), amyl alcohol (Merck, PT.Dipa Prasa Husada), methanol (Smartlab, PT.Dipa Prasa Husada), FeCl3 (Merck, PT.Dipa Prasa Husada), $\mathrm{NaCl}$ (Merck, PT.Dipa Prasa Husada), gelatin (Lokal, PT.Dipa Prasa Husada), vanillin sulfate (China, PT.Dipa Prasa Husada), liebermen burchard, n-hexane (Merck, PT.Dipa Prasa Husada), ethyl acetate (Merck, PT.Dipa Prasa Husada).

\subsection{Methods}

\subsubsection{Test Animal Acclimatization}

The animals used were white male Wistar rats weighing $200-220$ gram with an age of 3-4 months. Has been declared ethically worthy with the Ethical Clearance number No.032/kepk-bth/IV/2021. Mice were acclimatized for 1 week to adapt to the 
new environment.

\subsubsection{Crude Extract Preparation}

Mango leaves (Mangifera longipes G.)

were sorted wet, washed, dried, sorted dry, chopped and made into powder by means of a blender.

\subsubsection{Crude Extract Characteristic}

Evaluation for crud extract characteristics was conducted including macroscopic, microscopic tests, determination of water content, determination of total ash content, determination of water soluble extract content and determination of ethanol soluble extract content.

\subsubsection{Extraction}

Maceration extraction method was used, with 500 gram of crude extract powder inserted into the macerator and soaked in methanol for 24 hours 3 times. The extracts was taken to filter every 24 hours. The filtrate was collected and concentrated using a rotary vacuum evaporator at a temperature of $78.8^{\circ} \mathrm{C}$.

\subsubsection{Fractionation}

The concentrated extract was then fractionated with distilled water and n-hexane 3 times. The n-hexane fraction was concentrated. The aquadest residue was partitioned with ethyl acetate 3 times. Then the aquadest residue and the ethyl acetate fraction were concentrated. ${ }^{12}$

\subsubsection{Phytochemical Screening}

Phytochemical screening of samples was conducted to determine the metabolite seconder of chemical compounds contained in mango leaves (Mangifera longipes Griff.). It included for examination of alkaloids, flavonoids, saponins, phenols, tannins, monoterpenes/sesquiterpenes, steroids, and triterpenoids.

\subsubsection{Alcohol Free Test}

The extract/fraction was added with $\mathrm{H}^{2} \mathrm{SO}^{4}(\mathrm{p})$, then added $\left(\mathrm{CH}^{3} \mathrm{COOH}\right)$, then heated. If there is an ester odor, the results indicate the presence of alcohol in the extract/ fraction. ${ }^{13}$

\subsubsection{Antidiabetic Activity Evaluation}

The method used is the Oral Glucose Tolerance Test (OGTT). After acclimatization, the rats were then fasted for 8 hours before being given treatment, then given glucose induction (except the normal group). 30 minutes later, the blood glucose level $(\mathrm{T} \neg 0)$ was checked, then acarbose test preparation was given $1.8 \mathrm{mg} / 200$ gram body weight of rats (positive group), methanol extract 58.8 $\mathrm{mg} / 200$ gram of body weight of rats (EM), water fraction $58.8 \mathrm{mg} / 200$ gram BW rats (FA), ethyl acetate fraction $58.8 \mathrm{mg} / 200$ grams BW rats (FEA), aquadest ad libitum (negative group). 120 minutes later, the blood glucose level (T120) was checked. Checking blood glucose levels is done with a glucometer.

\subsubsection{Statistical Data Analysis}

Data were analyzed using SPSS version 16.0 application with normality test, homogeneity test, ANOVA, LSD test, and paired $t$ test.

\section{Results}

3.1 BiosintesisCrude Extract Characteristic Testing

The simple macroscopic test of mango leaves showed that mango leaf had a distinctive odor, green color, and a bitter taste. The results can be seen in Table 1.

From the microscopic test of mango leaf crude extract, it was found that there were bundles of vessels, and epidermis can be seen in Figure 1.

In the standardization of mango leaf crude extract, the results were $2 \%$ water content, $12.6 \%$ ash content, $19.5 \%$ water soluble extract content, $31.3 \%$ ethanol soluble extract content. The results can be seen in Table 2.

Table 1. Mango Leaf Macroscopic

\begin{tabular}{cc}
\hline Parameter & Information \\
\hline Smell & Typical \\
Color & Green \\
Taste & Bitter \\
\hline
\end{tabular}




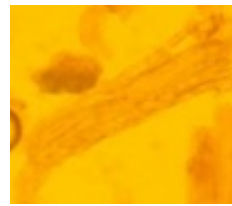

(a)

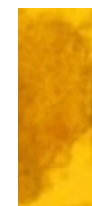

(b)

Figure 1. Mango Leaf Microscopy

Table 2. Standardization of Mango Leaf Crude Extract

\begin{tabular}{cc}
\hline Parameter & Percentage (\%) \\
\hline Water content & 2 \\
Ash content & 12,6 \\
Water soluble extract & 19,5 \\
Ethanol soluble extract & 31,3 \\
\hline
\end{tabular}

\subsection{Phytochemical Screening}

From the results of phytochemical screening on crude extract and extracts identified flavonoids, saponins, and phenols; water fraction identified saponins and phenols; the ethyl acetate fraction identified flavonoids and phenols. The results can be seen in Table 3.

\subsection{Extract Yield}

The yield obtained in the methanol extract was $19.4 \%$, the water fraction was $41.03 \%$, the ethyl acetate fraction was $28.2 \%$, and the n-hexane fraction was $18.4 \%$. The results can be seen in Table 4 .

\subsection{Alcohol Free Test}

The methanol extract, water fraction, and ethyl acetate fraction did not show any ester odor. The results can be seen in Table 5 .

\subsection{Antidiabetic Activity Test}

The average blood glucose levels of rats in each treatment group at $\mathrm{T} 0$ decreased at $\mathrm{T} 120 \%$. The decrease in blood glucose levels of rats in the positive group was $85.5 \%$, extract $-33.8 \%$, water fraction $-40.6 \%$, ethyl acetate fraction $16.9 \%$. The results can be seen in Table 6.

\subsection{Statistical Data Analysis}

The data are normally distributed and homogeneous. The paired t test showed that the normal, positive group, methanol extract, water fraction, and ethyl acetate fraction showed a significant decrease in blood glucose levels.

\section{Discussion}

Penambahan sPlant determination aims to determine the identity of the plants used as research. The purpose of standardization of crude extract is to maintain stability and safety, as well as to maintain the consistency of the content of active compounds contained in crude extract. ${ }^{14}$ The phenolic bioactives

Table 3. Phytochemical Screening

\begin{tabular}{ccccc}
\hline Compound & Crude Extract & EM & FA & FEA \\
\hline Alcaloid & - & - & - & - \\
Flavonoid & + & + & - & + \\
Saponin & + & + & + & - \\
Phenol & + & + & + & + \\
Tannin & - & - & - & - \\
Monoterpen/Sescuiterpen & - & - & - & - \\
Steroid/ & - & - & - & - \\
Triterpenoid & & & & \\
\hline
\end{tabular}

$(+)$ identified; (-) not identified 
Table 4. Rendemen

\begin{tabular}{cc}
\hline Dossage & Rendemen (\%) \\
\hline EM & 19,4 \\
FA & 41,03 \\
FEA & 28,2 \\
\hline
\end{tabular}

Table 5. Alcohol Free Test

\begin{tabular}{cl}
\hline Dossage & Hasil \\
\hline EM & No smell of ester \\
FA & No smell of ester \\
FEA & No smell of ester \\
\hline
\end{tabular}

Table 6. Average and Standard Deviation of Blood Glucose Level

\begin{tabular}{ccccc}
\hline Group & To & TI20 & Decrease & \% Decrease \\
\hline Normal & $96 \pm 11,5$ & $78 \pm 16,6$ & $18 \pm 6,6$ & - \\
Negative & $152,7 \pm 39,5$ & $123,2 \pm 21,9$ & $29,5 \pm 20,2$ & - \\
Positive & $174,2 \pm 24,2$ & $119,5 \pm 30,07$ & $54,7 \pm 23,3$ & $85,5 \%$ \\
EM & $117,5 \pm 3,2$ & $98 \pm 8,6$ & $19,5 \pm 6,5$ & $-33,8 \%$ \\
FA & $116,7 \pm 11,7$ & $99,2 \pm 7,7$ & $17,5 \pm 8,1$ & $-40,6 \%$ \\
FEA & $129,2 \pm 8,4$ & $94,7 \pm 6,1$ & $34,5 \pm 13,04$ & $16,9 \%$ \\
\hline
\end{tabular}

To $=30$ minutes after induction, except for the normal group ; $\mathrm{T} \neg 120=120$ menit after administration of the preparation, except for the normal group; Decrease $=$ The difference in blood glucose levels 120 minutes and 30 minutes after induction, except for the normal group.

from mango leaves have activity as antiinflammatory, anti-oxidant, and inhibiting $\alpha$-glucosidase. ${ }^{15}$ Flavonoid compounds are thought to increase the activity of antioxidant enzymes and can regenerate damaged pancreatic $\beta$-cells, so that later insulin deficiency does not occur. ${ }^{16}$ In addition, mango plants are a source of mangiferin. ${ }^{9}$ Mangiferin belongs to the flavonoid group and belongs to xantone. Where this mangiferin has activity as an antidiabetic by inhibiting the $\alpha$-glucosidase enzyme. Based on the Paired T Test, it showed that there was a significant difference in blood glucose levels at T0 and T120, showing a significant 2 -tailed value $<0.05$. This paired $t$ test was conducted to compare two data in a comparative manner. Significant differences are indicated by a significance value of $<0.05$. The paired $t$ test showed that there was a significant difference in the decrease in blood glucose levels in the normal group (0.018), the positive group (0.027), the extract group $(0.014)$, the water fraction group (0.034), and the ethyl acetate fraction group (0.020).

Mangiferin can be used as an antidiabetic by inhibiting $\alpha$-glucosidase8.

In the research of Irondi et al., 2016 a study was conducted on the antidiabetic effect of Mangifera indica kernel flour with Streptozotocin induction in rats. The results of this study showed that the administration of Mangifera indica kernel flour decreased fasting blood sugar levels. This was due to the fact that Mangifera indica kernel flour contains flavonoid and felolic acid compounds, and the meetanol extract can inhibit the enzymes $\alpha$-amylase, $\alpha$-glucosidase, and also aldose reductase, where these enzymes are associated with type 2 diabetes. ${ }^{17}$ The $\alpha$-amylase enzyme plays a role in hydrolyzing $\alpha-1,4$ glycosidic carbohydrates, which triggers the molecular breakdown of oligosaccharides to pass 
through the intestinal epithelium. It can also absorb glucose in the intestines, which in turn can prevent its systematic absorption. ${ }^{18}$

Decreased glucose levels in rats can be caused by the mechanism of action of mango leaf extract by inhibiting $\alpha$-amylase (reducing postprandial hyperglycemia and also preventing the development of diabetes), reducing glucose absorption (reducing glucose through the intestinal lumen, can reduce postprandial hyperglycemia), eliminating free radicals will induce cell damage, in the presence of antioxidants from mango leaves free radicals will be neutralized, so that it will protect cells from the toxic effects of free radicals, can also prevent pathogenesis and complications of diabetes mellitus), inhibitors of Nitric Oxide production (high levels of NO can produce free radicals). peroxynitrite which can harm cells, will later bind to proteins and affect). ${ }^{19}$ Mangiferin may also have pancreatic and extrapancreatic mechanisms as antidiabetic, so that its dual action on the pancreas and extrapancreas is better than oral antidiabetic monotherapy. ${ }^{20}$ The results of this study as described previously, where mango leaves can reduce blood glucose levels.

\section{Conclusion}

From this study, it can be concluded that the methanol extract, water fraction, and ethyl acetate fraction have antidiabetic activity with the best percentage reduction in blood glucose levels produced by the ethyl acetate fraction (16.9\%).Conclusions are based on the study results and linked to the objectives of the study.

\section{References}

1. Soelistijo, S. A., Lindarto, D., Decroli, E., Permana, H., Sucipto, K. W., Kusnadi, Y., Budiman, Ikhsan, R., Sasiarini, L., \& Sanusi, H. Pedoman Pengelolaan dan Pencegahan Diabetes Melitus Tipe 2 Dewasa di Indonesia. 2019. PB PERKENI.

2. World Health Organization. 2019. Classification of Diabetes Mellitus 2019. World Health Organization.

3. World Health Organization. Diabetes.
World Health Organization. 2020. https:// www.who.int/news-room/fact-sheets/ detail/diabetes.

4. American Diabetes Association. 2019. Diabetes Care.

5. Jutiviboonsuk, A., \& Sardsaengjun, C. Mangiferin in Leaves of Three Thai Mango (Mangifera indica L.) Varieties. 2010; 6(3): 122-129.

6. Lin, H., Teng, H., Wu, W., Li, Y., Lv, G., Huang, X., Yan, W., \& Lin, Z. Pharmacokinetic and metabolomic analyses of Mangiferin calcium salt in rat models of type 2 diabetes and nonalcoholic fatty liver disease. 2020; 21 (59). https://doi.org/10.1186/s40360-02000438-x

7. Sarkar, P., Bhowmick, A., Kalita, M. C., \& Banu, S. Effects of Resveratrol and Mangiferin on PPAR $\gamma$ and FALDH Gene Expressions in Adipose Tissue of Streptozotocin-Nicotinamide-Induced Diabetes in Rats. Journal of Dietary Supplements. 2019; 16(6):659-675. https://doi.org/10.1080/19390211.2018.1 472714.

8. Kulkarni, V. M., \& Rathod, V. K. Exploring the Potential of Mangifera indica Leaves Extract Versus Mangiferin for Therapeutic Application. Agriculture and Natural Resources. 2018; 52(2): 1-20.https://doi. org/10.1016/j.anres.2018.07.001.

9. Mahdiyah, L. L. Z. T., Muhtadi, A., \& Hasanah, A. N. Teknik Isolasi dan Penentuan Struktur Mangiferin: Senyawa Aktif dari Tanaman Mangga (Mangifera indica L.). Majalah Farmasetika. 2020; 5(4) : 167-179. https://doi.org/10.24198/ mfarmasetika.v5i4.27238

10. Ichiki, H., Miura, T., Kubo, M., Ishihara, E., Komatsu, Y., Tanigawa, K., \& Okada, M. New Antidiabetic Compounds, Mangiferin and Its Glucoside. 1998; 21(12): 1389-1390. https://www.jstage.jst.go.jp/article/ bpb1993/17/11/17_11_1460/_pdf/-char/ ja.

11. Syah, M. I., Suwendar, \& Mulqie, L. Uji Aktivitas Antidiabetes Ekstrak Etanol Daun Mangga Arumanis (Mangifera 
Indica L. "Arumanis") pada Mencit Swiss Webster Jantan dengan Metode Tes Toleransi Glukosa Oral (Ttgo). Prosiding Penelitian Sivitas Akademika UNISBA. 2015: 297-303.

12. Rahmawati, I., Noviana, S., \& Rinanto, Y. Uji Aktivitas Antifungi Fraksi n-Heksan, Etil Asetat, dan Air dari Daun Pepaya (Carica Papaya Linn.) terhadap Candida albicans ATCC 10231. Jurnal Farmasi Indonesia. 2010; 7(1): 30-34.

13. Kurniawati, E. Daya Antibakteri Ekstrak Etanol Tunas Bambu Apus Terhadap Bakteri Escherichia coli dan Staphylococcus aureus Secara In Vitro. Jurnal Wiyata. 2015; 2(2): 193-199.

14. Utami, Y. P., Umar, A. H., Syahruni, R., \& Kadullah, I. Standardisasi Simplisia dan Ekstrak Etanol Daun Leilem (Clerodendrum minahassae Teisjm. \& Binn.). Journal of Pharmaceutical and Medicinal Sciences. 2017; 2(1): 32-39.

15. Pan, J., Yi, X., Zhang, S., Cheng, J., Wang, Y., Liu, C., \& He, X. Bioactive Phenolics From Mango Leaves (Mangifera indica L.). Industrial Crops \& Products. 2018; 111 : 400-406. https://doi.org/10.1016/j. indcrop.2017.10.057.

16. Rahayuningsih, N., \& Amelia, S. Uji Aktivitas Antidiabetes Infusa Daun Pohpohan (Pilea trinervia Wight.) Pada Mencit Putih Jantan Galur Swiss Webster. Jurnal Kesehatan Bakti Tunas Husada. 2015; 13(1): 89-94.

17. Irondi, E. A., Oboh, G., \& Akindahunsi, A. A. Antidiabetic effects of Mangifera indica Kernel Flour-supplemented diet in streptozotocin-induced type 2 diabetes in rats. Food Science and Nutrition. 2016; 1-12. https://doi.org/10.1002/fsn3.348.

18. Villas Boas, G. R., Lemos, J. o. M. R., De Oliveira, M. W., Dos Santos, R. C., Da Silveira, A. P. S., Bacha, F. B., Ito, C. N. A., Cornelius, E. B., Lima, F. B., Rodrigues, A. M. S., Costa, N. B., Bittencourt, F. F., Fe Lima, F. F., Paes, M. M., Gubert, P., \& Oesterreich, S. A. Aqueous extract from Mangifera indica Linn. (Anacardiaceae) leaves exerts long-term hypoglycemic effect, increases insulin sensitivity and plasma insulin levels on diabetic Wistar rats. PLoS ONE. 2020; 15(1), 1-19. https://doi.org/10.1371/journal. pone. 0227105 .

19. Ngo, D. H., Ngo, D. N., Vo, T. T. N., \& Vo, T. S. Mechanism of action of Mangifera indica leaves for anti-diabetic activity. Scientia Pharmaceutica. 2019; 87(13), 1-12. https://doi.org/10.3390/ scipharm8702001.

20. Muruganandan, S., Srinivasan, K., Gupta, S., Gupta, P. K., \& Lal, J. Effect of mangiferin on hyperglycemia and atherogenicity in streptozotocin diabetic rats. Journal of Ethnopharmacology. 2005; 97(3), 497-501. https://doi.org/10.1016/j. jep.2004.12.010. 